\title{
CONSUMER BEHAVIOR TOWARDS SHOPPING MALLS: A SYSTEMATIC NARRATIVE REVIEW
}

\author{
Shahzad Nasim \\ Hamdard Institute of Education and Social Sciences, Faculty of Social Sciences and \\ Humanities, Hamdard University, Karachi \\ Musarrat Shamshir \\ Associate Professor, Hamdard Institute of Education and Social Sciences, Faculty of Social \\ Sciences and Humanities, Hamdard University, Karachi
}

\begin{abstract}
The purpose of the study is to recognize the factors that influence the consumer's behavior towards shopping centers. Along with this study endeavors have been made to investigate different components which influence the consumer behavior towards shopping mall. This literature review found the consumer preferences towards shopping mall. Customers do not go shopping mall only for shopping but also for entertainment. Different studies denote that there are numerous factors that appeal the customer towards shopping mall. This work will definitely help shopkeepers or retailers to make changes (if any) in the mall in order to attract customers and satisfying their needs and wants and also important for the development of a mall. After reexamining of 100 papers on consumer behavior towards shopping mall author recognized that shopping environment, ease of shopping, availability of different products, showbiz offered at malls, parking facility, good product quality, discount and sales promotion are the factors that convince the Shoppers to visit shopping malls with entertainment.
\end{abstract}

Keywords: Shopping Mall; Atmospheric factors; Consumer behavior

Jel Classification: L81, M31, Q56

*The material presented by the author does not necessarily portray the view point of the editors and the management of the Ilma University - Formerly IBT

1. Shahzad Nasim
2. Musarrat Shamshir

: shahzadnasim@live.com

:Musarrat Shamshir@gmail.com

CILMA-JBS is published by the Ilma University - Formerly IBT

Main Ibrahim Hydri Road, Korangi Creek, Karachi-75190, Pakistan 


\section{INTRODUCTION}

Consumers not merely obtain practical benefits; however additionally look for emotional benefits like enjoyment and refreshment. To understand the psychology of shoppers, it's imperative to understand the role of consumers' emotions. Consumers' feeling gets influenced as before long as he/ she moves in an exceedingly searching area (Albrecht et al., 2017). Numerous scholars have studied how consumers' emotions get influenced when consumers enter in a retail store (e.g. Albrecht et al., 2017; Kim et al., 2016a, 2016 b; Rayburn and Voss, 2013). At this time visualize a customer walking into a shopping mall and gets fascinated by its interior designs, lightings, people roaming around, and on-going promotional events before entering into a retail store. How would these mall atmospherics influence his shopping mall behavior? The present work is an effort to answer this question. Thinking about shopping in a shopping center as a social movement and recreational action, prior works featured the significance of meaningful gestures and limited time signals (Yim et al., 2014).In accordance with these works, it was additionally underlined that apparent human and spatial shopping center swarming, limited time occasions, and the nearness of co-guests may influence general buyers' shopping and esteem observations (Yim et al., 2014). There are sixteen striking characteristics which focalize into the accompanying four primary measurements that can be considered as determinants of shopping center engaging quality: (1) Merchandising (2) Variety \& selection (3) Environment \& facilities, and (4) convenience (Mittala Amit, 2016).Baker (1994) claimed that store environment has significant impact on store image by facilitating customer through product and service quality. To find the different opportunities customer rely on physical signals and physical indication, such as the appearance and layout of the physical facilities, when consumers visit shopping malls, they look for experiences that go well beyond traditional shopping (Zeithaml ,1993).

The quality perception for stores among consumers depends upon their education and income. The physical attributes, quality of product, high prices and color scheme inside the store represent its quality (Wheatley, 1997). Store reputation having warranty has a significant impact on consumer buying behavior (Thorelli, 1997). According to Stephen (1997) Consumers' perceptions of retail image are associated with brand features, mindfulness about products quality and perceptions of retail image.

To explain the consumer behavior situational variables are as important as consumer characteristics (Belk, 1975). Knowledge of the attributes of the malls and consumer's value use to distinguish between stores and the awareness about importance of attributes are needed by retailers for procurement and supporting a strategic competitive advantage in retailing.

\section{LITERATURE REVIEW}

\subsection{Consumer Behavior}

Consumer behavior is the investigation of people, gatherings, or associations and every one of the exercises related with the buy, utilize and transfer of products and enterprises, including the consumer's emotional, mental and behavioral reactions that go before or take after these exercises.Buyer conduct is the investigation of how particular clients, gatherings or associations select, purchase, utilize, and arrange thoughts, merchandise, and administrations to fulfill their requirements and needs. It indicates to the activities of the purchasers in the commercial center and the hidden thought processes in those activities. 


\subsection{Shopping Mall}

A Shopping Mall can be considered as collection or congregation of various stores offering different brands, products or services at one place. A shopping center has numerous shops and organizations can rent/purchase these shops for setting up their own particular stores. Shopping malls are a noteworthy financial environment in a city and they drive monetary and social advancement.

\subsection{Highlights of Shopping Malls}

Sirgy (1984) found that store image has a significant relationship between utilitarian and value-expressive attributes of store. There are four factors "socioeconomic status," "pleasantness," "dependability," and "friendliness." that impact the retail store (Lutz, 1988).

\subsection{Exterior Design of Shopping Mall}

According to Ackerberg (2001) in shopping mall, exterior atmosphere of the store plays an important role in building a first impression of a retail store and attracting customers whereas advertising has only a minor and insignificant effect on experienced consumers. Retailors can extend the consumer behavior towards shopping mall by making their outside atmosphere more charming to purchasers and to stimulate their walks into the store and enable their purchase desire (Shareef Ishar Ali Mohamed, 2015).Infra structure of the store attracts the customers and unique features of the store entrance has significant impression on the minds of its customers. Store appearance should be desirable. When self-image and customer image of customer matches, it increase the satisfaction level of the customer (Devlin, 2003). The exterior design of the outlet is associated with the emotional effects on the consumer that cause to enhance his purchasing probability (Kotler, 1973-74).

According to Harvinder (2013) shopping at malls in Dubai based on five factors: marketing focus, physical infra-structure, ambience, safety and security. According to Alam(2012) factors like quality, accessibility, suitability of the product, facility to entertain, food facility and overall service affect the customer's buying attitude towards shopping mall. Unique shopping experience is important for the retailers that starts with the store exterior, when customers like the exterior atmosphere of the retail store; they experienced higher pleasure and arousal, which increased purchase intentions (Sangvikar, 2012).Exterior atmospheric factors, for example, store appearance, arranging and window show has positive impact on shoppers'behavior(Shareef Ishar Ali1 Mohamed, 2013). Among other atmospheric factors exterior atmospheric factors are the great importance for a retail store .

Consumer's intention about shopping may influence by exterior design of the store (Mower, 2012) moreover location of the store also important for the customer and for retailors. For making customer satisfied it is necessary that fulfill the desire of the customers (Feng-Chuan Pan, 2008).Mohamed (2013) examine in Sri Lanka the power of exterior atmosphere of mall on consumer behavior. He also found that how to inspire the customer at entrance to the store and motivate their purchase intention.According to Prashar (2013) shopping mall requires appropriate layout and design to attract higher level of customers towards shoppers. To become successful retailer, it is necessary that they will be able to differentiate from their competitors through exterior atmosphere attractiveness for consumers and to encourage them towards their purchase intention. 


\subsection{Location /Convenient}

Divaries (2013) described that several factors can attract the customers towards buying behavior one of the most important factor is location of the store. According to Sinha ( 2004) the super stores are becoming more popular among the customers in the developing countries due to their prime location and multiple services for customers.

The visit of customer to the shopping mall also depends upon the distance from the residence of customer and also on the transportation expenses visit duration, and visiting day (van, 2014). Different customer like different characteristics of malls and different consumer has different taste and choices of products (Sirgy Joseph, 2014).Some features that fascinate the customer towards shopping mall are store location, travelling time, convenience, proximity to complimentary outlets and store visibility. Patience (2013) described that better parking space fascinated high income employees on the other side the mall that has no parking area create the traffic jam problem for the consumers as well as for the other citizen.

To make the shopping easier super stores plays a vital role. They provide a lot of facilities like variety of products under one roof, good and pleasant environment, entertainment area for kids etc. This examine in India that the geographical area also plays important role in motivating buying behavior of young consumers (Srivastava, 2016).In traditional stores located in India examine the moderating effect of relationship between distances travelled by customers and the customer perceptions of store and also found that customer perception and store attributes are positively interrelated (Mishra, 2013).

\subsection{Interior Design of Shopping Mall}

It has been observed that the amount of shopping centers in Malaysia has enlarged significantly, as well as been liable to constant extension in the course of recent years regardless of rate of development, there has not been sufficient consideration paid to the nature of the spaces and inside finishing of the shopping centers based on individuals' inclinations. There are three noteworthy measurements: the green measurement, the seating measurement, and the business measurement in open spaces of shopping centers where the green measurement got the most amazing inclination (Hamia Ahmad, 2018).

According to Mazhar (2015) atmospheric variables, for instance, orderliness, aroma, lighting, and show/outline influence purchasers' purchase point; however music and shading have insignificant impact on purchasers' purchase objective. The temperature has no impact on the purchase objective of the buyers. This was the essential examination, which investigated the total impact of natural components at one point in time on purchase point. This investigation was causal in nature. A sample of 300 consumers was taken who usually visited these outlets. Data was gathered through structured survey questionnaire and analyzed through regression analysis.

\subsection{Layout/Design of the window}

Harimukti (2012) observes during a survey that store atmosphere and design has significant impact on customer's sales. Store design and store atmosphere may cause consumers to purchase more amount of merchandise. The factors that may increase the sales of products are space, layout, display and entrance, dressing rooms, atmosphere, colour, lighting and fragrance around the mall.Sinha(2004) emphasizes on the store design and atmosphere as the key drivers besides quality and variety of products. 
Consumers preference concerning different products depends upon reshaping and window display of product.The store window and the first look to attract the customer are important before entering in the store. Customers visits the shopping mall not only for shopping but also for entertainment that provides fun and pleasure from the shopping experience (Kim, 2011).

\subsection{Pleasant Environment}

In the accomplishment of retail outlet, role of store atmosphere cannot be ignored. The social interaction in new generation is very important and may be created through providing enjoyable atmosphere in shopping mall. Uncles (2010) anticipated that Chinese customers are attracted by modern, fresh and appealing retail stores and shopping mallsmost anticipated element of retail chain outlets is a pleasant atmosphere (Turley, 2000).

Consumer knows the importance of store environment. According to Gopal (2015) different groups of store characteristics affect various consumer-based retailer equity CBRE magnitudes inversely.Atmospheric factors including lighting, scent, cleanliness and display have a positive impact on consumers' buying intention; while music and color have consequential impact on consumers' buying intention (Mazhar, 2015).

Additional facilities in the store attracts the customers and they love to going for shopping at night specially.People want to enjoy all fascinating attributes in the store and also demand for security and convenience. Sellers should focus on the favorites of their consumers and the factors influencing their purchase decision (Priyanka ,2014). Enjoyable environment, store communication, stylish appearance of the store has significant effect on consumer's emotions (Tibert, 2011). Multimedia, multichannel and retailing environment has fully-fledged assortment in scope and sophistication of store image (Dholakia, 2010).

\subsection{Color and Light}

Sipho (2016) discover that due to attractive features of shopping mall consumers visit the shopping mall frequently. To attract customer towards shopping mall it is necessary to use the color and light combination according to modern design techniques which can enhance the market opportunities (Warakul, 2016).

According to Joseph (1982) fiction of self-concept in consumer behavior can be considered as fragmented, confused, and highly verbose. Memories, thoughts, and experiences may be stimulated from lightening. "For instance; the retail stores having red environment usually gives a negative and tense impact and less attractive than blue and green" (Bellizzi, 1983).According to Jean (2007) choice of color also influence the consumer towards shopping mall. It is not necessary that every consumer like light color decor in the mall.

\subsection{Fragrance, Music and Technological Factors}

Khalaf (2012) highlighted the factors like convenience, entertainment, aesthetic and service quality have a positive impact on shoppers in Saudi shopping malls. Variety of products were found the most significant factor among all factors. Consumer purchase intention is more influenced by atmospheric variables like hygiene, aroma, light, and presentation/layout of the product while music and décor have inconsequential effect on consumers' purchase intention (Hussain, 2015). Through structured scale store image can easily be measured. Structured scale is more correlated with two types of measures that 
have same properties that's why researchers use structured, semantic differential scales to measure store image attributes (Jhinuk, 2015).

Motivational level and factors of shopping for students are changed from others in term of products and generation (Lester, 2005). The ambient aromas, atmosphere and perceptions of product superiority have significant impact on consumer's emotions and on visions of the retailer under various level of retail concentration (Chebat, 2005).

Relationship between store atmosphere and buying behavior can be moderated by age. The store environments can improve the buying behavior of their customers through the marketers and the retail managers. According to Ahmed (2017) Food court, malls position, mall security and parking area are the key attributes of any mall to increase the consumer. These factors can help the sellers for promotion of their products and also for the progress of shopping mall.

The study from Bhubaneswar (2015) found that Impulsive buying plays an important role in consumer buying behavior in Chennai. Accessibility of personal computers, internet access, downloading time and speed, pictures and colors of products' representativeness are some of the technological factors that are the reason for growing the potential customer.

\subsection{Reason of Shopping in shopping Mall}

The buyers visit the shopping center on account of specific reasons and the frequencies of visits of these purchasers change as per their desire(Selatole, 2016).Shopping mall might be beneficial for the retailors and shoppers as shopping malls has major impact of social interaction, significant shopping strategies and entertainment on consumers (Zafar, 2007). According to Roy (1999) female are more interested in shopping as compare to male. Due to time limitations female feel free to go shopping in the mall and it is also a basic source of mental relaxation for the women specially.

Karachi weather usually remains warm and very dirty so the customers love to visit shopping centers which have enjoyable atmosphere and the occurrence and difficulty of impulse buying shoppers changes their malls environment (Sharma, 2010).

Shopping prosperity at the shopping center as a customer's apparent effects shopping center as adding to fulfillment in imperative life areas bringing about a worldwide judgment that the shopping center contributes fundamentally to one's general quality(Hedhl Kamel El i, 2011). The link between store choice characteristics, shopping motives, and risk can generate through store image that will ultimately suggest implications for store growth, placing approaches, and employees training (Mitchell, 2001) while different mall studies have clear the discriminant qualities but some studies provide innovative insight into consumers' thinking and few have tried to explain how these attributes lead to the fulfillment of individual shopping motives. Four main hazard scopes (time, financial, psychosocial, physical) can linked the shopping reasons and store qualities and again reschedule previous store qualities under supposed risk magnitudes (Ronald, 2000).

Perception of consumers towards characteristics of stores effects their preference. Attributes of stores have meaningful impacts on consumer preferences, some of them are marketing, convenience, status and atmosphere of the stores (Chze, 2003) . 
Choudhury(2012) proposed that quality, price, facility to socialize, entertainment and overall services have a significant impact on customer's attitude towards shopping mall.

Consumer behavior towards shopping mall depends upon the perceptions of the customer about the shopping mall. Chithralega (2013) Found during the survey in Chennai that mall atmosphere positively affects the primary motivation and their shopping value.Dealers, retailers and trader should considered store environment. The emotions of clients are important for shoppers as a management tool (Sabrina, 2014).

Mathai (2016) examine that major entertaining activity for the families is the shopping with enjoyment that's why shopping mall attributes are highly associated with fun filled action for the customers to make them joyful. It is observed in India that consumers prefer shopping in the mall where they can eat food, can do window shopping, can watch movies and can play games under the one roof (Krishan, 2016).

\subsection{Customer Satisfaction}

To understand the consumers' psychology two important principles are examined from attribution theory a) expected likelihood of product satisfaction stimulate through discernments of causality along a stability b) decisions of accountability and punitive actions influence from discernments of causality along a controllability measurement (Bernard, 2000). There are two main types of magnitude on which construction of store image depends that are tangible magnitude and intangible magnitudes (Steve, 2000).Attractiveness of a waiting area has been associated with higher levels of customer satisfaction (Pruyn, 1998).

Feroz (2007) described that selection of shopping mall depends upon level of the consumers' satisfaction. Price of commodities and availability of goods can impact the selection of shopping mall. Feedback of customers can create the image of mall. Brand image is so much important for customer satisfaction. Customers enjoy the clean and pleasant environment of malls.

In shopping mall existence of durable goods are very common. The type of product influences the performance of shoppers and sellers. Durable goods as compare to nutritional products are likely to sell more that improve the seller's performance (Davies, 2013).

According to Akram (2016) several factors can influence the impulse buying behavior as an unplanned purchasing decision. The relationship between store stmosphere and buying behaviour can effected by demographic variables such as age, gender and education.

\section{METHODOLOGY}

A systematic and descriptive literature review of more than hundred (100) research articles has been conducted on the title as mention above.Narrative review, also known as an unsystematic narrative review. Unsystematic narrative review or story diagram are complete narrative syntheses of formerly published information. Narrative overviews can be a valuable contribution to the literature for research scholars if organized appropriately. The details of how to prepare this type of commentary are presented in this section (Bart N. Green, 2006). 
The following databases were searched to identify therecords for the current descriptive review on consumer behavior towards shopping malls: Elsevier,Springer,Sage,Taylor and Francis,Emerald Insight, National Digital Library and some journals are mentioned here as ;Procedia Economics And Finance(2016),International Review Of Management And Business Research International Journal Of Science And Research (Ijsr), International Journal Of Marketing Studies,International Journal Of Retail \& Distribution Management,Journal Of Chiropractic Medicine,Journal Of Business Research(2011),Urban Forestry And Urban Greening(2018),Services Marketing Quarterly, 62-76,International University Journal of Business And Economics, International Journal Of Business Quantitative Economics And Applied Management Research , International Marketing Review.

During the revisiting of the articles author focused on consumer behavior towards shopping trends and on features of store image including interior and exterior design of the shopping mall, entrance of the shopping mall, inner lay out of the product design, fragrance and food court area in the mall that attracts the customers. Reviewed article are interrelated to the consumer and shopping malls.

\subsection{Literature Search and Inclusion Criteria Diagram}



Figure 1.Literature search diagram.This diagram was constructed according to American Psychological Association Meta-Analysis Reporting Standards (MARS) 


\section{CONCLUSION}

The review of literature related to consumer behavior can be consider as disjointed, jumbled, and highly verbose (Joseph, 1982).This study gathers and evaluates very interesting facts and figures based on the previous researches on consumer behavior towards shopping mall. The study concludes that;

Store design and store atmosphere has a significant effect on the shopping experience. Several features like display of the products, music, lay out; space, window display and entrance have an impact on consumer behavior towards shopping mall and increase the sales. The study concludes that facility of having convenience to socializing, parking space, food quality and entertainment effects customers' attitude towards shopping mall. Other factors like store appearance, redesigning and window presentation of outlets also affects consumers' purchasing behavior. Atmospheric factors like scent or fragrance, lightning, cleanliness, music and colors have an impact on consumers towards shopping at the mall. Consumers like to revisit malls if they are facilitated by waiting room, enjoyable atmosphere. The exterior as well as interior design of the mall are important to attract consumers and have a very strong relationship with their emotions as well. The study also concludes that besides other factors parking space, distance from the mall and transportation expenses also play an important role in consumers' purchasing in malls.

\section{REFERENCES}

Baker, J. G. (1994). The Influence Store Environment On Quality Inferences And Store Image. Journal Of The Academy Of The Marketing Science. 22, 4, 328-

Turley, L. M. (2000). Atmospheric Effects On Shopping Behavior: A Review Of The Experimental Evidence. Journal Of Business Research 49,, 193-211.

Selatole, S. (2016). Determining consumers' reasons for visiting. research gate.

Kotler, P. (1973). Atmospherics As A Marketing Tool. Journal Of Retailing Retailing, Vol. 49, 48.64.

Amanor-Boadu, V. (2009). In Search Of A Theory Of Shopping Value: The Case Of Rural Consumers. Review Of Agricultural Economics, Vol. 31 No. 3, 589-603.

Buttle, F. (1992). 'Shopping Motives: Constructionist Perspective. The Services Industries Journal, Vol. 12 No. 3, 349-367.

Shareef Ishar Ali1 Mohamed, M. M. (2013). Exterior Atmospherics and There Impact on. International Journal of Science and Research (IJSR).

Lester, D. F. (2005). 'Internet Shopping And Buying Behavior Of College Students. Services Marketing Quarterly, Vol. 27 No. 2, 123-138.

O'guinn, T. A. (1989). Compulsive Buying: A Phenomenological Exploration. Journal Of Consumer Research, Vol. 16 No. 2, 147-157

Rook, D. A. (1995). Trait And Normative Aspects Of Impulsive Buying Behavior. Journal Of Consumer Research, Vol. 22 No. 3, 305-313.

Bellizzi, J. A. (1983). The Effects Of Color In Store Design. Journal Of Retailing, 59(1), 2147.

Awan, A. (2007). The Ultimate Shopper's Paradise. The Review. July 5-11, The Daily Dawn, Islamabad., 12. 
Arnold, M. A. (2003). “Affect And Retail Shopping Behavior: Understanding The Role Of Mood Regulation And Regulatory Focus. Journal Of Retailing, Vol. 85 No. 3, 308320.

Verplanken, B. A. (2001). Individual Differences In Impulse Buying Tendency: Feeling And No Thinking. European Journal Of Personality, Vol. 15 No. 1,, 71-83.

Lee, G. A. (2008). The Effect Of Shopping Emotions And Perceived Risk On Impulsive Buying The Moderating Role Of Buying Impulsiveness Trait. Seoul Journal Of Business, Vol. 41 No. 2, 67-92.

Achmad, F. Y. (2014). The Influence Of Brand Image On Purchase Behaviour Through Brand Trust . Business Management And Strategy .

Ahmed, M. A. ( March 2017 ). Latest Buyer's Need In Shopping Malls. Ibmrd's Journal Of Management \& Research .

Ajay, K. (September 2014 ). A Study Of Key Factor Affecting Customer Relationship Towards Shopping Mall . International Journal Of Business Quantitative Economics And Applied Management Research ,Volume 1, Issue 4.

Ali Shareef, I. M. (2015). Exterior Atmospherics And There Impact On Consumer Purchasing Behavior At Self- Serving Convenience Stores. International Journal Of Science And Research (Ijsr).

Bashir, S. (March 2013). Impact Of Cultural Values And Life Style On Impulse Buying Behavior: A Case Study Of Pakistan. International Review Of Management And Business Research.

Bhuvaneswari, K. J. (2015). A Review Of Literature On Impulse Buying Behaviour Of Consumers In Brick \& Mortar And Click Only Stores. International Journal Of Management Research And Social Science (Ijmrss).

Choudhury Afreen, A. I. (June 2012). Customers' Attitude Towards Shopping Malls: A Study On Bashundhara City Shopping Mall. D.U. Journal Of Marketing, Vol. No. 15.

Ekeng, E. A. (2012). Effect Of Demographic Characteristics On Consumer Impulse Buying Among Consumers Of Calabar Municipality, Cross River State. Academic Research International.

Exterior Atmospherics And Their Impact On Consumer Purchasing Behavior At SelfServing Convenience Stores. (N.D.).

Mazhar1, H. R. (2015). Effect Of Store Atmosphere On Consumer Purchase Intention. International Journal Of Marketing Studies; Vol. 7, No. 2.

Mohamed, I. A. (2013). Exterior Atmospherics And There Impact On Consumer Purchasing Behavior At Self- Serving Convenience Stores . International Journal Of Science And Research (Ijsr) .

Nyengerai Sarah. (2014). Household Size And Brand Perception: The Case Of Store Brands In Zimbabwe. International Journal Of Academic Research In Business And Social Sciences.

Patience, J. C. (2013). The Role Of Store Location In Influencing Customers' Store Choice . Journal Of Emerging Trends In Economics And Management Sciences (Jetems) 4(3), 302-307 .

Sipho, M. (2016). Determining Consumers' Reasons For Visiting Shopping Malls. Innovative Marketing, Volume 12, Issue 2, .

Priyanka Singh, N. K. (2014). Retail Shoppability: The Impact Of Store Atmospherics \& Store Layout On Consumer Buying Patterns. International Journal Of Scientific \& Technology Research, 3(8), 15-23.

Sabrina. (2014). The Influence Of The Store Atmosphere On The Consumer Behavior. Mediterranean Journal Of Social Sciences, 5(8),, 229-235. 
Feng-Chuan Pan., S.-J. S.-C. (2008). Dual Attractiveness Of Winery: Atmospheric Cues On Purchasing. International Journal Of Wine Business Research, , 20(2), 95-110

Sangvikar, B. V. (2012). A Study Of Consumer Purchase Behavior In Organized Retail Outlets. Journal Of Business And Retail Management Research (Jbrmr), 7(1),, 39-47.

Haiyan Hu., C. R. (2006). Social Cues In The Store Environment And Their Impact On Store Image. . International Journal Of Retail \& Distribution Management, 34(1), 25-48.

Devlin, D. B. (2003). Food Retail Positioning Strategy: A Means-End Chain Analysis. British Food Journal, 105 (9), 653.

Sen, S. B. (2002). Xwindow displays and consumer shopping decisions, . Journal of Retailing and Consumer Services, 9,27

Kim K.P, J. H.-Y. (2015). Keeping customers shopping in stores: interrelationships among store attributes, shopping enjoyment, and place attachment. The International Review of Retail, Distribution and Consumer Research, 25(1), 20-34.

Edwards, S. A. (1992). Measuring the effectiveness of retail window display as an element of the marketing mix,. International Journal of Advertising, 11(3),, 193-202.

Belk, R. (1975). Situational variables and consumer behavior. Journal of Consumer Research $2,157-164$.

Ryan, I. C. (2002). "Food-related lifestyle segments in Ireland with a convenience orientation. Journal of International Food \& Agribusiness Marketing, Vol. 14 No. 4,, 29-47.

Kotler, P. (1973). Atmospherics as a Marketing Tool. Journal of Retailing Retailing, Vol. 49, 48.64 .

Wakefield, K. L. (1998). Excitement at the mall: Determinants and effects on shopping response. Journal of Retailing 74, no. 4 , 515-39.

Sinha, P. K. (2004). Store choice behaviour in an evolving market. Int. J. Of Retail \& Distribution Management. Vol. 32, No. 10, 482-494.

The environment of shopping mall encourages the desire of customers to stay and purchase the goods. (Wakefield, 1998).

Akram, U. E. (2016). Impact of Store Atmosphere on Impulse Buying Behaviour: Moderating Effect of Demographic Variables. International Journal of u- and eService, Science and Technology.

Awng, D. (2008). Consumers' Perceptions Toward Retail Stores Comparing Between Superstores And Family-Run Stores In Bangkok. Shinawatra University.

J.Chithralega. (2013). A Study On Influence Of Shopping Motivation, Mall Atmosphere And Value Relationship With Reference To Mega Malls In Chennai . International Journal Of Marketing, Financial Services \& Management Research.

Srivastava, A. A. (2016). "Brand analysis of global and local banks in India: a study of young consumers. Journal of Indian Business Research, Vol. 8 No. 1, 4-18.

Taylor, S. (1994). "Waiting for service: the relationship between delays and evaluations of service. Journal of Marketing, Vol. 58 No. 2 , 56-69

Uncles, M. (2010). "Retail change in China: retrospect and prospects. International Review of Retail, Distribution and Consumer Research, Vol. 20 No. 1,, 69-84.

Stefan Roth, L. H. (2017). Does unit pricing influence store price image dimensions and shopping intentions for retail stores? European Journal of Marketing, Vol. 51 Issue: 7/8, 1-34.

Pruyn, A. A. (1998). Effects of waiting on the satisfaction with the service: beyond objective time measures. International Journal of Research in Marketing, Vol. 15 No. 4, 321-34.

Sharma, P. S. (2010). Impulse buying and Variety seeking: A trait-correlates perspective. Journal of Business Research, 63, 276-283. 
Ackerberg, D. (2001). 'Empirically distinguishing informative and prestige effects of advertising'. Rand Journal of Economics, 316-333.

Zeithaml, V. B. (1993). "The nature and determinants of customer expectations of service. Journal of the Academy of Marketing Science, Vol. 21, No. 1, 1-12.

Padilla-Walker, L. F. (2015). Associations between friendship, sympathy, and prosocial behavior toward friends. Journal of Research on Adolescence, Vol. 25 No. 1, 28-35.

Bloemer, J. (1998). On the relationship between store image, store satisfaction and store loyalty. European Journal of Marketing.

Chze, L. D. (2003). Linking consumer perception to preference of retail stores: an empirical assessment of the multi-attributes of store image. Journal of Retailing and Consumer Services.

Colleen, D. C. (2003). Store brands and retail differentiation: the influence of store image and store brand attitude on store own brand perceptions. Journal of Retailing and Consumer Services.

Divaries, J. ( 2013 ). The Role of Store Location in Influencing Customers' Store Choice. Journal of Emerging Trends in Economics and Management Sciences .

Feroz, A. (2007). Consumers Attitude towards Modernized Shopping Center vs. Traditional Shopping Center - A Case Study at Khulna City. Daffodil International University Journal of Business and Economics.

Janjaap, S. (2004). Consumer evaluations of store brands: effects of store image and product attributes. Journal of Retailing and Consumer Services.

Jhinuk, C. (2015). Alternative Modes of Measuring Store Image: An Empirical Assessment of Structured versus Unstructured Measures. Journal of Marketing Theory and Practice.

Josee, B. (1998). On the relationship between store image, store satisfaction and store loyalty. European Journal of Marketing.

Lutz, H. (1988). Store image and the prediction of performance in retailing. Journal of Business Research.

Prashar, P. (2013). Factors Defining Shopping Experience: An Analytical Study of Dubai. Asian Journal of Business Research.

Rita, M. (2007). Corporate brand image, satisfaction and store loyalty: A study of the store as a brand, store brands and manufacturer brands. International Journal of Retail \& Distribution Management.

Stephen, P. (1997). The influence of brand recognition on retail store image. Journal of Product \& Brand Management.

Alam, S. I. (2012). Customers' attitude towards shopping malls: a study on bashundhara city shopping mall. D.u. Journal Of Marketing, Vol. No. 15.

Harimukti, B. A. (2012). Store Design And Store Atmosphere Effect On Customer Sales Per Visit . 2nd International Conference On Business, Economics, Management And Behavioral Sciences .

Harvinder, S. ( 2013 ). Factors Defining Shopping Experience: An Analytical Study Of Dubai . Asian Journal Of Business Research ISSN1178-8933 Volume 3 Number 1 .

Khalaf Mohammad, A. A. (2012). Attractiveness Factors Influencing Shoppers' Satisfaction, Loyalty, And Word Of Mouth: An Empirical Investigation Of Saudi Arabia Shopping Malls. International Journal Of Business Administration.

Manzano Roberto, M. A. ( 2011). Experiential Shopping At The Mall: Influence On Consumer Behaviour. China-USA Business Review.

Joseph, S. (1982). Self-Concept in Consumer Behavior: A Critical Review. Journal of Consumer Research, Volume 9, Issue 3, Pages 287-300. 
Marios, K. (2000). Applying the Technology Acceptance Model and Flow Theory to Online Consumer Behavior. Information System Research.

Bernard, W. (2000). Attributional Thoughts about Consumer Behavior. Journal of Consumer Research, Pages 382-387.

Mitchell. (2001). Re-conceptualizing consumer store image processing using perceived risk. Journal of Business Research, 167-172.

Ronald, E. (2000). Atmospheric Effects on Shopping Behavior: A Review of the Experimental Evidence. Journal of Business Research, Pages 193-211.

Joseph, S. (1982). Self-Concept in Consumer Behavior: A Critical Review. Journal of Consumer Research, Volume 9, Issue 3, Pages 287-300.

John, B. (2002). Losing Consciousness: Automatic Influences on Consumer Judgment, Behavior, and Motivation. Journal of Consumer Research, Volume 29, Pages 280285.

Marieke, M. (2002). Convergence and divergence in consumer behavior: implications for international retailing. Journal of Retailing, Pages 61-69.

Jean, C. (2007). Colors and cultures: Exploring the effects of mall décor on consumer perceptions. Journal of Business Research.

Mower. (2012). Exterior atmospherics and consumer behavior: Influence of landscaping and window display. Journal of Fashion Marketing and Management.

Dholakia, e. A. (2010 ). Consumer Behavior in a Multichannel, Multimedia Retailing Environment. Journal of Interactive Marketing, Pages 86-95.

Chebat, E. A. (2005). Mall atmospherics: the interaction effects of the mall environment on shopping behavior. Journal of Business Research.

Arjun, M. (2013). E-commerce: It's Impact on consumer Behavior . Global Journal of Management and Business Studies. , 131-138 .

Peter, W. (2014). Consumer Response to Introduction of Paid Parking at a Regional Shopping Center. Journal of the Transportation Research Board.

Van, d. W. (2014). Consumer Response to Introduction of Paid Parking at a Regional Shopping Center. Journal of the Transportation Research Board.

Warakul, T. (2016). Effects of color and lighting on retail impression and identity. Journal of Environmental Psychology.

Stephen, P. (1997). The Influence Of Brand Recognition On Retail Store Image. Journal Of Product \& Brand Management.

Davies. (2013). Evaluation Of Retail Store Attributes And Sales Performance. European Journal Of Marketing.

Dimple, K. (2016). Exploring The Link Between Customer Experience-Loyalty-Consumer Spend. Journal Of Retailing And Consumer Services.

Gopal, D. (2015). Impact Of Store Attributes On Consumer-Based Retailer Equity: An Exploratory Study Of Department Retail Stores. Journal Of Fashion Marketing And Management.

Hartman, K. (2005). Recapturing Store Image In Customer-Based Store Equity: A Construct Conceptualization. Journal Of Business Research, 1112-1120.

Hussain, R. (2015). Effect Of Store Atmosphere On Consumer Purchase Intention. International Journal Of Marketing Studies.

Jhinuk, C. (2015). Alternative Modes Of Measuring Store Image: An Empirical Assessment Of Structured Versus Unstructured Measures. Journal Of Marketing Theory And Practice, 72-86.

Krishan, P. (2016). Consumer Buying Perception And Preferences Towards Organized Retailing: An Empirical Analysis Of Shopping Malls In Lucknow. A Journal of Management Sciences. 
Mathai, S. T. (2016). Materialism: Its Impact On Impulse Buying Behaviour Among The Retail Customers Of Cochin. International Journal Of Management Research \&Review, 647-658.

Mishra, S. K. (2013). Customer Perceptions For Store Attributes: A Study Of Traditional Retail Stores In India . Journal Of Business \&Economics, 79-103.

Sirgy, T. V. (1984). The Interrelationship Of Utilitarian And Value-Expressive Store Image Attributes. Academy Of Marketing Science (AMS).

Steve, B. (2000). The Role Of Store Image In Retail Internationalisation. INTERNATIONAL MARKETING REVIEW, 433-453.

Thorelli, E. A. (1997). Relative Importance Of Country Of Origin, Warranty, And Retail Store Image On Product Evaluations. International Marketing Review.

Wheatley, C. A. (1997). The Effects Of Price, Store Image, And Product And Respondent Characteristics On Perceptions Of Quality. Journal Of Marketing Research, 181-186.

Andrew, P. (2003). Assessing The Effectiveness Of Shopping Mall Promotions: Customer Analysis. INTERNATIONAL JOURNAL OF RETAIL \& DISTRIBUTION MANAGEMENT, 74-79.

Bloch Peter, E. (1994). The Shopping Mall As Consumer Habitat. Journal Of Retailing, 3242.

Joseph, S. M. (1982). Self-Concept In Consumer Behavior: A Critical Review. Journal Of Consumer Research, Volume 9, Issue 3, 287-300.

Kim Ji Wan, L. F. (2015). Satisfaction And Loyalty From Shopping Mall Experience And Brand Personality. Services Marketing Quarterly, 62-76.

Roy, D. R. (1999). Going Shopping: Key Determinants Of Shopping Behaviors And Motivations. International Journal Of Retail \& Distribution Management, Vol. 27 Issue: $4,154-165$.

Zafar, A. (2007). Malaysian Shopping Mall Behavior: An Exploratory Study. Asia Pacific Journal Of Marketing And Logistics, Vol. 19 Issue: 4, 331-348,

Albrecht, C.M., Hattula, S., Lehmann, D.R., 2017. The relationship between consumer shopping stress and purchase abandonment in task-oriented and recreation-oriented consumers. J. Acad. Mark. Sci. 1-21.

Kwon, H., Ha, S., Im, H., 2016. The impact of perceived similarity to other customers on shopping mall satisfaction. J. Retail. Consum. Serv. 28, 304-309

Kim, S., Park, G., Lee, Y., Choi, S., 2016 b. Customer emotions and their triggers in luxury retail: understanding the effects of customer emotions before and after entering a luxury shop. J. Bus. Res. 69 (12), 5809-5818.

Yim, M.Y.C., Yoo, S.C., Sauer, P.L., Seo, J.H., 2014. Hedonic shopping motivation and co shopper influence on utilitarian grocery shopping in superstores. J. Acad. Mark. Sci. 42 (5), 528-544.

Hedhl Kamel El i, C. J.-C. (2011). Shopping well-being at the mall: Construct, antecedents, and consequences. elsevier.

Hamia Ahmad, F. M. (2018). Public preferences toward shopping mall interior landscape design in Kuala. Elsevier.

Mazhar, H. R. (2015). Effect of Store Atmosphere on Consumer Purchase Intention. International Journal of Marketing Studies.

Shareef Ishar Ali Mohamed, M. M. (2015). Exterior Atmospherics and There Impact on. International Journal of Science and Research (IJSR).

Bart N. Green, a. C. (2006). Writing narrative literature reviews for peer-reviewed journals: secrets of the trade. Journal of chiropractic medicine, 101-117. 